\title{
Reciprocating and Rotatory NiTi Instruments Used for Root Canal Preparation of Primary Teeth: A Systematic Review and Meta-Analysis
}

\author{
Laura Izabel Lampert Bonzanini ${ }^{1}$, Cleber Paradzinski Cavalheiro ${ }^{1}$,, Maitê Munhoz Scherer ${ }^{1}$, \\ Djessica Pedrotti ${ }^{\circledR}$, Paola Arosi Bottezini ${ }^{1}$, Ricardo Abreu da Rosa ${ }^{\circledR}$, Luciano Casagrande ${ }^{1}(\mathbb{0}$, \\ Tathiane Larissa Lenzi1 10
}

\begin{abstract}
'Post-Graduate Program in Pediatric Dentistry, School of Dentistry, Federal University of Rio Grande do Sul, Porto Alegre, RS, Brazil.

${ }^{2}$ Post-Graduate Program in Endodontics, School of Dentistry, Federal University of Rio Grande do Sul, Porto Alegre, RS, Brazil.
\end{abstract}

Correspondence: Tathiane L. Lenzi, School of Dentistry, Post-Graduate Program in Pediatric Dentistry, Federal University of Rio Grande do Sul, Ramiro Barcelos 2492, Santa Cecília, Porto Alegre, RS, Brazil. 90035 -003. E-mail: tathiane.lenzi@ufrgs.br

Academic Editor: Alessandro Leite Cavalcanti

Received: 26 January 2021 / Review: 09 March 2021 / Accepted: 10 April 2021

How to cite: Bonzanini LIL, Cavalheiro CP, Scherer MM, Pedrotti D, Bottezini PA, Rosa RA, Casagrande L, Lenzi TL. Reciprocating and rotatory NiTi instruments used for root canal preparation of primary teeth: a systematic review and meta-analysis. Pesqui Bras Odontopediatria Clín Integr. 2021; 21 :e0016. https://doi.org/10.1590/pboci.202 1.124

\begin{abstract}
Objective: To compare the root canal preparation of primary teeth with reciprocating and rotary NiTi instruments. Material and Methods: Electronic databases (PubMed/MEDLINE, Web of Science, TRIP, Lilacs, Embase, and Scopus) were systematically searched until October 2020. In vitro studies comparing the cleaning ability, debris extrusion, file deformation, or working time of rotary and reciprocating NiTi instruments in primary teeth were evaluated. Two reviewers independently selected the studies, extracted the data, and assessed the risk of bias. Meta-analyses were conducted using a random-effects model to calculate pooled mean differences between reciprocating and rotary NiTi instruments considering the outcomes: working time (minutes) and debris extrusion (milligrams). Statistical analyses were performed using RevMan 5.3 at a significance level of $5 \%$. Results: From 4,417 potentially relevant studies, 10 were included in the systematic review, and 8 considered in the meta-analyses. There was no significant difference between reciprocating and rotary NiTi instruments considering debris extrusion [ 3 data sets; effect size: -0.11 (-0.25-0.04); $\mathrm{p}=0.15]$ and working time [6 data sets; effect size: -0.37 (-0.98-0.24); $\mathrm{p}=0.24]$. The heterogeneity found was moderate to high. The risk of bias was low in most studies $(50.0 \%$ of all items across studies). Conclusion: There is no scientific evidence showing superiority of reciprocating or rotary NiTi instruments used for root canal preparation in primary teeth.
\end{abstract}

Keywords: Root Canal Preparation; Systematic Review; Tooth, Deciduous. 


\section{Introduction}

The main objective of endodontic treatment is to maintain the integrity of the primary teeth with irreversibly infected or necrotic pulp due to caries or trauma [1]. The maintenance of primary teeth has a positive impact on oral functions and prevents alterations in chronology and eruption sequence of permanent teeth [2]. In addition, the biomechanical preparation has a critical role in the treatment success since the cleaning and shaping of the root canals aid in the removal of the infected pulp tissue, provide access for irrigating solutions to reach the apical third of root, and further allow adequate obturation of the prepared root canals [3].

Hand instrumentation is still considered as the principal choice of cleaning and shaping of the primary root canals; however, its use has been associated with the possibility of perforations, dentin compaction, ledge formation, and instrument fracture [4]. On the other hand, mechanical instrumentation presents better results than hand instrumentation, resulting in more centered preparations and a smaller number of lateral perforations and canal transportation [5]. Moreover, mechanical instrumentation minimizes the clinical time, which is a very interesting aspect to consider for pediatric patients [6].

Rotary and reciprocating nickel-titanium (NiTi) instruments are commercially available for mechanical root canal preparation. Rotary NiTi instruments are designed to be used in continuous rotary motion at different speeds and torque according to the NiTi alloy, heat treatment, and tip and taper of the instrument [7]. In 2007, the concept of reciprocating motion was presented [8]. This kinematic aimed to reduce the cyclic fatigue of $\mathrm{NiTi}$ instruments by means of intermittent clockwise and counterclockwise rotation. Thenceforth, reciprocating instruments have been developed and improved for root canal preparations, showing higher cyclic fatigue resistance than rotatory NiTi instruments [8].

The scientific literature reveals a lack of clinical trials comparing both kinematics, especially for treatment of primary teeth. Pooled in vitro data may provide more useful information for pediatric dentists to choose any rotary or reciprocating system for endodontic treatment in primary teeth. As efficient canal preparation is an important step to successful endodontic treatment, different outcomes should be considered, such as cleaning efficacy, debris extrusion, file deformation, and working time.

Therefore, this systematic review aimed to compare the root canal preparation of primary teeth with rotary and reciprocating NiTi instruments.

\section{Material and Methods}

The protocol was registered in the PROSPERO database (Registration number CRD42020152505) and this study was reported according to the Preferred Reporting Items for Systematic Reviews and MetaAnalyses (PRISMA) statement [9]. Furthermore, this study has followed the CRIS guidelines for in vitro studies, as discussed in the concept note [10].

\section{Focused PICOS Question}

The following research question was formulated to address the literature and outline the search strategy: Is there a difference between the rotary and reciprocating NiTi instruments for root canal preparation of primary teeth considering the cleaning ability, debris extrusion, file deformation or working time?

- Population: Human primary teeth 
- Intervention: Reciprocating NiTi instruments

- Comparison: Rotary NiTi instruments

- Outcomes: Cleaning ability, debris extrusion, file deformation or working time

- Study Design: in vitro studies

\section{Data Sources and Search Strategy}

A comprehensive literature search was undertaken through PubMed/MEDLINE, Web of Science, Turning Research Into Practice (TRIP), Lilacs, Embase, and Scopus databases to identify studies related to the research question and published up to October 2020. The search was conducted with no publication year or language restrictions. Initially, the subject search used a combination of controlled vocabulary and text words based on the search strategy in the PubMed/MEDLINE database. Then, the search strategy was adapted for other databases (Supplementary appendix). The results of searching the various databases were cross-checked to find and remove duplicates.

The inclusion criterion was in vitro studies that evaluated reciprocating and rotary NiTi instruments for root canal preparation in primary teeth. The exclusion criteria were: 1) did not consider debris extrusion, working time, file deformation or cleaning ability as outcomes; 2) did not use the same irrigating solution during root canal preparation with both instruments.

\section{Search Steps: Screening and Selection}

Step 1: Titles and abstracts were independently reviewed by two authors (L.L.B and M.M.S.) and selected for further review if they met the inclusion criterion. The inter-examiner agreement $($ Kappa $=1.00)$ calculation indicated excellent agreement.

Step 2: Full-text articles of studies selected in the previous step were retrieved and independently reviewed by two authors (L.L.B and M.M.S.) based on exclusion criteria. The reference list of all articles selected in this step was examined and the full texts of potentially interesting studies for the research question were evaluated.

Any disagreement in either step was first resolved by discussion between the reviewers (L.L.B and M.M.S.). A third author (C. P. C.) was consulted if discrepancies remained.

\section{Data Extraction}

Both reviewers independently collected the data from the eligible studies. Thus, the following data were systematically extracted from each paper: publication details (authors, year, country and language), sample characteristics (teeth type, sample size - number and type of root canals), methodology (rotary or reciprocating NiTi instruments - commercial names and manufacturers, number of instruments for system and protocol, irrigation solution for instrumentation, number of operators and evaluators), and outcome's information.

Assessment of the Risk of Bias

The reviewers also independently assessed the risk of bias according to the Cochrane Handbook for Systematic Reviews of Interventions [11], based on following criteria: randomization of teeth, description of sample size calculation, rotary and reciprocating NiTi instruments used according to the manufacturer's 
instructions, root canal preparation performed by a single operator and blinding of the examiner. The studies were evaluated by rating each domain as having low, high, or unclear risk of bias (no information or uncertainty over the potential for bias). Disagreements between the reviewers were resolved by consensus for the final risk of bias classification.

\section{Data Analysis}

Meta-analyses were conducted using a random-effects model to calculate pooled mean differences between reciprocating and rotary NiTi instruments considering the working time (minutes) and debris extrusion (milligrams). The working time was measured with a digital chronometer and included the time taken for instrumentation, instrument change (when necessary), shaping, and irrigation of the root canals. Apically extruded debris and irrigant were collected, dried, and weighed using Eppendorf tube. The net weight of the dry debris was calculated by subtracting the weight of the empty Eppendorf tube from the total weight. The analyses were conducted with Review Manager Software (RevMan version 5.3 software, Cochrane Collaboration, Copenhagen, Denmark, 2014), considering a p-value < 0.05 as statistically significant (Z-test). In addition, statistical heterogeneity among studies was assessed via the Cochran $Q$ test and inconsistency $\left(I^{2}\right)$.

A descriptive analysis was performed for cleaning ability and file deformation. Four studies [12-15] considered cleaning ability as an outcome, but the measure unit varied among them. In addition, only one study [14] evaluated the file deformation using both NiTi instruments.

\section{Results}

The search strategy identified 4,417 potentially relevant studies, removing duplicates. After screening the titles and abstracts, 10 studies were assessed for more detailed information. None study was excluded after a full-text review. Therefore, 10 in vitro studies were included in this systematic review. Figure 1 presents a flowchart of the study selection process and the reasons for exclusions.

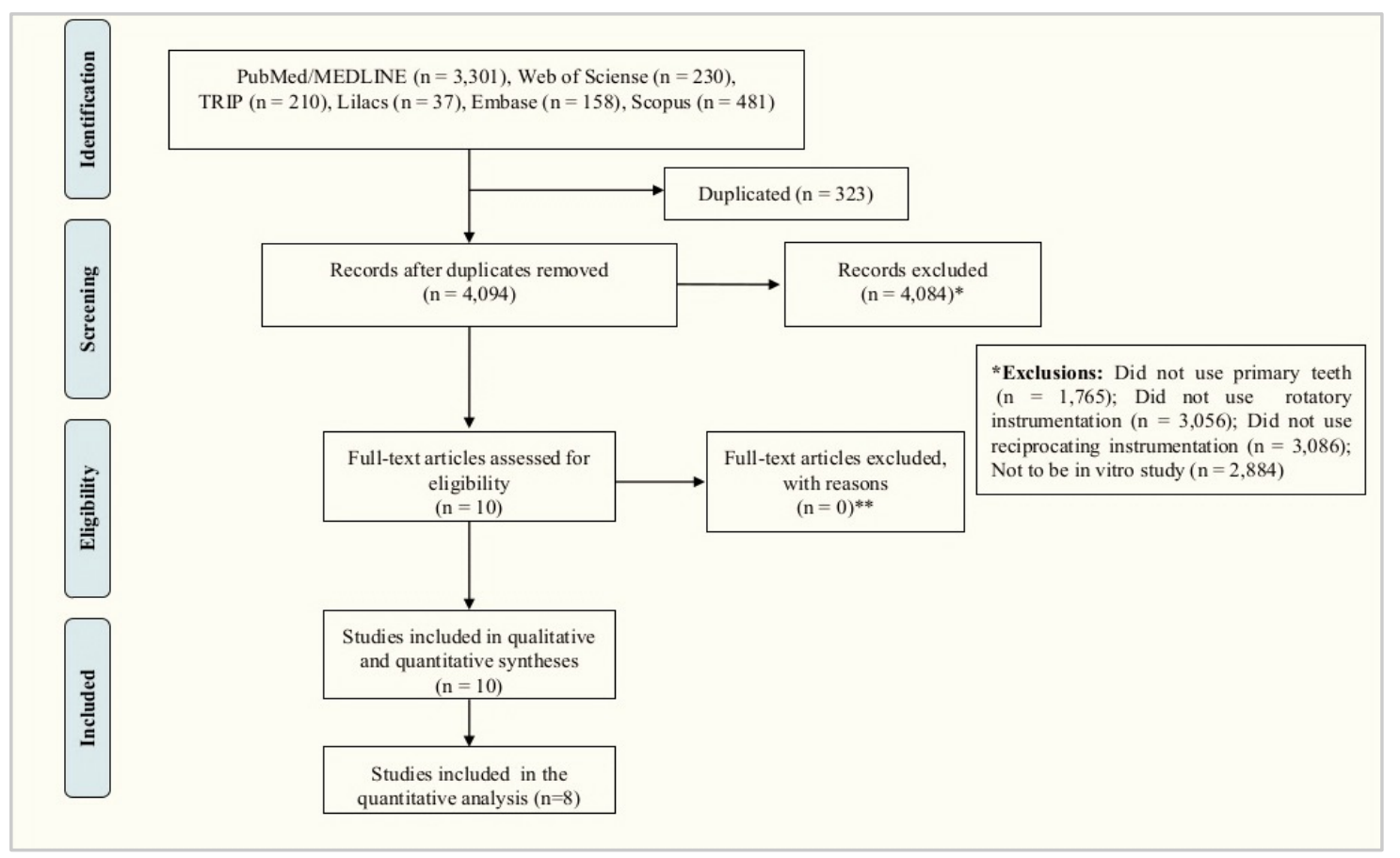

Figure 1. Flowchart of study selection according to PRISMA statement. 
Characteristics of the Included Studies

All studies were published in English and conducted in Brazil [13,15,16], India [12,17,18], Iran [14], Syria [19], and Turkey [20,21] and were reported between 2014 and 2020. Moreover, the studies included anterior or posterior human primary teeth. ProTaper [12,13,15,18-20] (Dentsply Maillefer, Ballaigues, Switzerland) and Wave-One (Dentsply Maillefer, Ballaigues, Switzerland) [12,13,15,17,19] systems were the most tested rotary and reciprocating instruments, respectively. A more detailed summary of the selected studies is shown in Table 1.

Table 1. Main characteristics of the in vitro selected studies for systematic review.

\begin{tabular}{|c|c|c|c|c|c|c|c|c|c|c|}
\hline Study & Country & $\begin{array}{l}\text { Type of Teeth } \\
\text { and Root } \\
\text { Canals }\end{array}$ & $\begin{array}{l}\text { Number } \\
\text { of Root } \\
\text { Canals }\end{array}$ & $\begin{array}{c}\text { Rotary System / Reciprocating } \\
\text { System Protocol }\end{array}$ & $\begin{array}{c}\text { Number of } \\
\text { Instruments per } \\
\text { System Rotary } \\
\text { System / } \\
\text { Reciprocating } \\
\text { System }\end{array}$ & $\begin{array}{c}\text { Chemical } \\
\text { Preparation }\end{array}$ & $\begin{array}{l}\text { Number of } \\
\text { Operators }\end{array}$ & $\begin{array}{l}\text { Number of } \\
\text { Examiners }\end{array}$ & $\begin{array}{l}\text { Outcome (s) of } \\
\text { the Studies }\end{array}$ & $\begin{array}{c}\text { Outcome (s) } \\
\text { Considered in } \\
\text { the } \\
\text { Systematic } \\
\text { Review }\end{array}$ \\
\hline $\begin{array}{l}\text { Alnassar et } \\
\text { al. 2019 } \\
\text { [19] }\end{array}$ & Syria & Molars/Distal & 16 & $\begin{array}{l}\text { ProTaper (Dentsply Maillefer, } \\
\text { Ballaigues, Switzerland) / Wave- } \\
\text { One (Dentsply Maillefer, Ballaigues, } \\
\text { Switzerland) } \\
\text { The root canals were prepared using } \\
\text { a manual \#10 K-file (Dentsply } \\
\text { Maillefer) to verify their patency. } \\
\text { - ProTaper system: X1 (size 17, } \\
\text { taper 0.04) and X2 (size 25, taper } \\
\text { 0.06). } \\
\text { - Wave-One system: one file (21/06) } \\
\text { was used with a reciprocal motion. }\end{array}$ & $2 / 1$ & $\begin{array}{c}\text { Distilled } \\
\text { water }(5 \mathrm{~mL})\end{array}$ & 1 & 1 & Extrusion debris & $\begin{array}{c}\text { Extrusion } \\
\text { debris }\end{array}$ \\
\hline $\begin{array}{l}\text { Barasuol et } \\
\text { al. } 2020 \\
{[16]}\end{array}$ & Brazil & $\begin{array}{l}\text { Molars / all } \\
\text { canals }\end{array}$ & 27 & $\begin{array}{l}\text { ProDesign Logic (Easy Dental } \\
\text { Equipment, Belo Horizonte, Brazil) / } \\
\text { Reciproc (VDW, Munich, Germany). } \\
\text { The root canal length was measured } \\
\text { using an adjusted file. } \\
\text { - ProDesign was used with the } \\
\text { motor (size 25.01) and ProDesign } \\
\text { Logic file (size 25.06) in continuous } \\
\text { rotation. } \\
\text { - Reciproc file: R25 (size 25.08) was } \\
\text { used with the motor in reciprocating } \\
\text { motion. }\end{array}$ & $2 / 1$ & $\begin{array}{l}\text { Sodium } \\
\text { hypochlorite } \\
(20 \mathrm{~mL})\end{array}$ & 1 & $\begin{array}{l}\text { Not } \\
\text { reported }\end{array}$ & $\begin{array}{l}\text { Working time } \\
\text { Shaping ability }\end{array}$ & Working time \\
\hline $\begin{array}{l}\text { Gungor and } \\
\text { Kustarci } \\
2016[21]\end{array}$ & Turkey & $\begin{array}{l}\text { Maxillary } \\
\text { molars / } \\
\text { Mesiobuccal }\end{array}$ & 15 & $\begin{array}{l}\text { Twist file Adaptive (SybronEndo, } \\
\text { Orange, CA, USA / } \\
\text { Reciproc (VDW, Munich, Germany) }\end{array}$ & $2 / 1$ & $\begin{array}{c}\text { Bidistilled } \\
\text { water }(6 \mathrm{~mL})\end{array}$ & 1 & 1 & Debris extrusion & $\begin{array}{l}\text { Debris } \\
\text { extrusion }\end{array}$ \\
\hline
\end{tabular}




\begin{tabular}{|c|c|c|c|c|c|c|c|c|c|c|}
\hline & & & & $\begin{array}{l}\text { The root canal length was measured } \\
\text { using a manual \#10 K-file. } \\
\text { - Twist file Adaptive: SM1 (20/0.04) } \\
\text { and SM2 (25/0.06). } \\
\text { - Reciproc: R25 Reciproc file (size } \\
\text { 25) with a taper of } 0.08 \text {. }\end{array}$ & & & & & & \\
\hline $\begin{array}{c}\text { Jeevanandan } \\
\text { and Thomas } \\
2018[18]\end{array}$ & India & $\begin{array}{l}\text { Mandibular } \\
\text { molars / } \\
\text { Mesiolingual }\end{array}$ & 20 & $\begin{array}{l}\text { ProTaper (Dentsply Maillefer, } \\
\text { Ballaigues, Switzerland) / TEP-ER } \\
10 \text { (NSK, Nakanishi, Japan) } \\
\text { - ProTaper system: the single file } \\
\text { was used till the working length. } \\
\text { - TEP-ER 10: } 15 \text { NiTi K- file to } \\
\text { No.30 NiTi- K- flex file, which was } \\
\text { coupled with NSK Endodontic } \\
\text { contra-angle with reciprocating } \\
\text { motion. }\end{array}$ & $1 / 2$ & $\begin{array}{l}\text { Saline solution } \\
\text { + EDTA }\end{array}$ & 1 & $\begin{array}{l}\text { Not } \\
\text { reported }\end{array}$ & $\begin{array}{l}\text { Working time } \\
\text { Volumetric } \\
\text { analysis }\end{array}$ & Working time \\
\hline $\begin{array}{c}\text { Katge et al. } \\
\qquad 2014 \\
{[12]}\end{array}$ & India & $\begin{array}{l}\text { Molars / Not } \\
\text { reported }\end{array}$ & 30 & $\begin{array}{l}\text { ProTaper (Dentsply Maillefer, } \\
\text { Ballaigues, Switzerland) / Wave- } \\
\text { One (Denstply Maillefer, Ballaigues, } \\
\text { Switzerland) } \\
\text { The root canals were prepared using } \\
\text { a manual \#10 K-file (Dentsply } \\
\text { Maillefer) to verify their patency. } \\
\text { - ProTaper system: SX and S2 file } \\
\text { were inserted untill the working } \\
\text { length. } \\
\text { - Wave-One system: Small file (6\% } \\
\text { taper). }\end{array}$ & $2 / 1$ & $\begin{array}{l}\text { Saline solution } \\
\quad(5 \mathrm{~mL})\end{array}$ & 1 & 1 & $\begin{array}{l}\text { Working time } \\
\text { Cleaning ability }\end{array}$ & $\begin{array}{l}\text { Working time } \\
\text { Cleaning } \\
\text { ability }\end{array}$ \\
\hline $\begin{array}{c}\text { Kucukyilmaz } \\
\text { et al. } 2015 \\
{[20]}\end{array}$ & Turkey & Canines / Single & 15 & $\begin{array}{l}\text { ProTaper (Dentsply Maillefer, } \\
\text { Ballaigues, Switzerland) / } \\
\text { Reciproc (VDW, Munich, Germany) } \\
\text { The root canal length was measured } \\
\text { using a manual \#15 K-file (Dentsply, } \\
\text { Maillefer, Ballaigues, Switzerland) } \\
\text { - ProTaper system: S1, S2, F1, F2. } \\
\text { - Reciproc system: R25 Reciproc file } \\
\text { (size 25) with a taper of } 0.08 \text { over the } \\
\text { first } 3 \mathrm{~mm} \text { was used. }\end{array}$ & $4 / 1$ & $\begin{array}{c}\text { Bidistilled } \\
\text { water }(4 \mathrm{~mL})\end{array}$ & 1 & 2 & $\begin{array}{l}\text { Working time } \\
\text { Debris extrusion }\end{array}$ & $\begin{array}{c}\text { Working time } \\
\text { Debris } \\
\text { extrusion }\end{array}$ \\
\hline $\begin{array}{c}\text { Pinheiro et } \\
\text { al. } 2016 \\
{[13]}\end{array}$ & Brazil & $\begin{array}{l}\text { Molars / all } \\
\text { canals }\end{array}$ & 20 & $\begin{array}{l}\text { ProTaper (Dentsply Maillefer, } \\
\text { Ballaigues, Switzerland) / } \\
\text { Wave-One (Dentsply Maillefer, } \\
\text { Ballaigues, Switzerland) } \\
\text { The root canals were prepared using } \\
\text { a manual \#10 K-file (Dentsply }\end{array}$ & $4 / 3$ & $\begin{array}{l}\text { Sodium } \\
\text { hypochlorite } \\
(4 \mathrm{~mL} \text { - } \\
\text { ProTaper, } \\
\text { 1mL - Wave- } \\
\text { One) }\end{array}$ & 1 & $\begin{array}{l}\text { Not } \\
\text { reported }\end{array}$ & $\begin{array}{l}\text { Cleaning ability } \\
\text { Working time }\end{array}$ & $\begin{array}{c}\begin{array}{c}\text { Cleaning } \\
\text { ability }\end{array} \\
\text { Working time }\end{array}$ \\
\hline
\end{tabular}




\begin{tabular}{|c|c|c|c|c|c|c|c|c|c|c|}
\hline & & & & $\begin{array}{l}\text { Maillefer) to verify their patency. } \\
\text { - ProTaper system: S1, S2 with } \\
\text { brushing motion and F1, F2 files } \\
\text { with back-and-forth motions. } \\
\text { - Wave-One system: small with } 0.06 \\
\text { taper; primary and large with } 0.08 \\
\text { taper. }\end{array}$ & & & & & & \\
\hline $\begin{array}{c}\text { Prabhakar et } \\
\text { al. } 2016 \\
{[17]}\end{array}$ & India & $\begin{array}{l}\text { Molars, Incisors } \\
\text { and Canines/ } \\
\text { Not reported }\end{array}$ & 28 & $\begin{array}{l}\text { One Shape (Micromega, Cedex, } \\
\text { France) / Wave-One (Dentsply } \\
\text { Maillefer, Ballaigues, Switzerland) } \\
\text { The root canal length was measured } \\
\text { using a manual \#10 K-file. } \\
\text { - Wave-One: single-file } \\
\text { - One-Shape: single-file }\end{array}$ & $1 / 1$ & $\begin{array}{c}\text { Sodium } \\
\text { hypochlorite }\end{array}$ & $\begin{array}{l}\text { Not } \\
\text { reported }\end{array}$ & $\begin{array}{l}\text { Not } \\
\text { reported }\end{array}$ & $\begin{array}{l}\text { Working time } \\
\text { Dentin thickness } \\
\text { Centering ability } \\
\text { Canal } \\
\text { transportation }\end{array}$ & Working time \\
\hline $\begin{array}{c}\text { Ramazani et } \\
\text { al. } 2016 \\
{[14]}\end{array}$ & Iran & $\begin{array}{l}\text { Mandibular } \\
\text { molars / } \\
\text { Mesiobuccal }\end{array}$ & 16 & $\begin{array}{l}\text { Mtwo Files (VDW GmbH, Munich, } \\
\text { Germany) / Reciproc (VDW GmbH, } \\
\text { Munich, Germany) } \\
\text { - Mtwo Files: 10/0.04, 15/0.05, } \\
\text { 20/0.06 and } 25 / 0.06 \text {. } \\
\text { - Reciproc system: Reciproc file (size } \\
\text { 25) with a taper of } 0.08 \text {. }\end{array}$ & $4 / 1$ & $\begin{array}{l}\text { Sodium } \\
\text { hypochlorite } \\
(5 \mathrm{~mL})\end{array}$ & 1 & 1 & $\begin{array}{l}\text { Cleaning ability } \\
\text { File deformation } \\
\text { Working time } \\
\text { Shaping ability }\end{array}$ & $\begin{array}{c}\text { Cleaning } \\
\text { ability } \\
\text { File } \\
\text { deformation } \\
\text { Working time }\end{array}$ \\
\hline $\begin{array}{l}\text { Silva et al. } \\
2018[15]\end{array}$ & Brazil & $\begin{array}{l}\text { Incisors and } \\
\text { Canines / all } \\
\text { canals }\end{array}$ & 12 & $\begin{array}{l}\text { ProTaper (Dentsply Maillefer, } \\
\text { Ballaigues, Switzerland) / Wave- } \\
\text { One (Dentsply Maillefer, Ballaigues, } \\
\text { Switzerland) } \\
\text { The root canal length was measured } \\
\text { using manual \#10 and \#20 K-files } \\
\text { (Dentsply Maillefer, Ballaigues, } \\
\text { Switzerland) } \\
\text { - Protaper: } 40 / 0.06 \\
\text { - Wave-One: } 40 / 0.08\end{array}$ & $1 / 1$ & $\begin{array}{l}\text { Sodium } \\
\text { hypochlorite } \\
(2 \mathrm{~mL})\end{array}$ & 1 & 2 & Cleaning ability & $\begin{array}{c}\text { Cleaning } \\
\text { ability }\end{array}$ \\
\hline
\end{tabular}

Assessment of the Risk of Bias

The final assessment of the risk of bias in the included studies is summarized in Table 2. Risk of bias was low in most studies (50.0\% of all items across studies). Only two studies $[14,16]$ described the method used to generate the random sequence and also two studies [16,20] reported the sample size calculation. Most studies reported that NiTi instruments were used according to the manufacturer's instructions and that a single operator performed the root canal preparation. Four studies [13,16-18] were scored as unclear risk of bias regarding blinding of the examiner because they did not report who performed the evaluations. 
Table 2. Assessment of the risk of bias of the selected studies.

\begin{tabular}{lccccc}
\hline Study & $\begin{array}{c}\text { Randomization Sample Size } \\
\text { of Teeth }\end{array}$ & $\begin{array}{c}\text { Kinematics } \\
\text { Calculation } \\
\text { Systems Used } \\
\text { according to the } \\
\text { Manufacturer's } \\
\text { Instructions }\end{array}$ & $\begin{array}{c}\text { Root Canals } \\
\text { Preparation } \\
\text { Single Operator }\end{array}$ & $\begin{array}{c}\text { Blinding of the } \\
\text { Examiner }\end{array}$ \\
\hline Alnassar et al. [19] & Unclear & High & Low & Low & Low \\
Barasuol et al. [16] & Low & Low & Low & Low & Unclear \\
Gungor and Kustarci [21] & Unclear & High & Low & Low & Low \\
Jeevanandan and Thomas [18] & Unclear & High & Unclear & Low & Unclear \\
Katge et al. [12] & Unclear & High & Low & Low & Low \\
Kucukyilmaz et al. [20] & Unclear & Low & Low & Low & Low \\
Pinheiro et al. [13] & Unclear & High & Unclear & Low & Unclear \\
Prabhakar et al. [17] & High & High & Low & Unclear & Unclear \\
Ramazani et al. [14] & Low & Unclear & Unclear & Low & Low \\
Silva et al. [15] & Unclear & High & Low & Low & Low \\
\hline
\end{tabular}

Meta-analyses

From the 10 studies included in the systematic review, 8 studies were included in the meta-analyses. A meta-analysis for debris extrusion was performed with 3 data sets [19-21], while a meta-analysis for working time was performed with 6 data sets $[12-14,16,18,20]$. There was no difference between reciprocating and rotary NiTi instruments considering debris extrusion [effect size: -0.11 (-0.25-0.04); p=0.15] (Figure 2) neither working time [effect size: -0.37 (-0.98-0.24); $\mathrm{p}=0.24]$ (Figure 3). The heterogeneity was found to be moderate $\left(\mathrm{I}^{2}=59 \%\right)$ and high $\left(\mathrm{I}^{2}=99 \%\right)$, respectively.

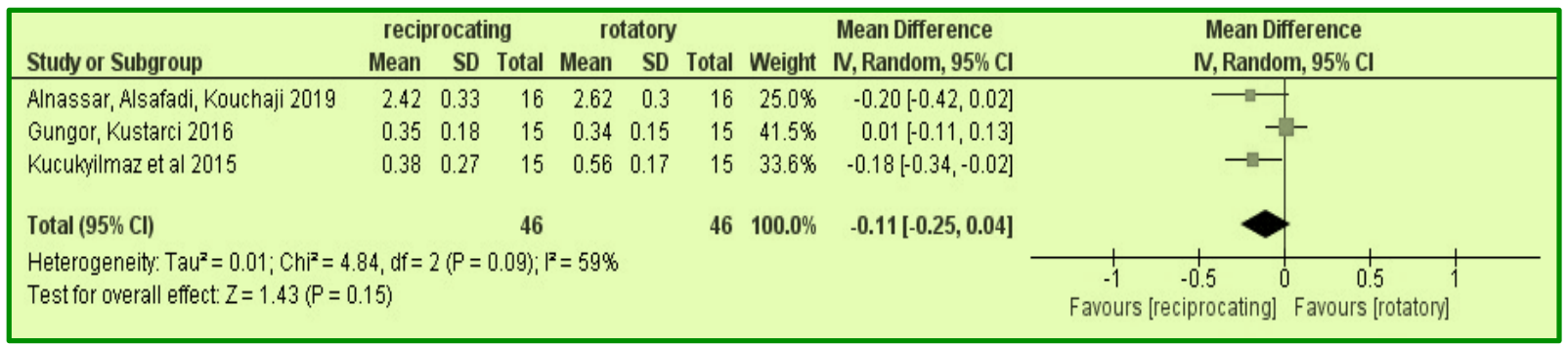

Figure 2. Meta-analysis considering debris extrusion (milligrams) as outcome.

\begin{tabular}{|c|c|c|c|c|c|c|c|c|c|}
\hline \multirow[b]{2}{*}{ Study or Subgroup } & \multicolumn{3}{|c|}{ reciprocating } & \multicolumn{3}{|c|}{ rotatory } & \multirow[b]{2}{*}{ Weight } & \multirow{2}{*}{$\begin{array}{l}\text { Mean Difference } \\
\text { IV, Random, } 95 \% \mathrm{Cl}\end{array}$} & \multirow{2}{*}{$\begin{array}{c}\text { Mean Difference } \\
\text { IV, Random, } 95 \% \mathrm{Cl}\end{array}$} \\
\hline & Mean & SD & Total & Mean & SD & Total & & & \\
\hline Barasuol et al., 2020 & 1.46 & 0.4 & 27 & 1.15 & 0.38 & 27 & $16.5 \%$ & $0.31[0.10,0.52]$ & |\# \\
\hline Jeevanandan, Thomas 2018 & 0.71 & 0.08 & 20 & 0.19 & 0.01 & 20 & $16.8 \%$ & $0.52[0.48,0.56]$ & - \\
\hline Katge et al., 2014 & 2.37 & 0.36 & 30 & 3.78 & 0.45 & 30 & $16.5 \%$ & $-1.41[-1.62,-1.20]$ & " \\
\hline Kucukyilmaz et al., 2015 & 0.87 & 0.25 & 15 & 1.64 & 0.27 & 15 & $16.6 \%$ & $-0.77[-0.96,-0.58]$ & " \\
\hline Pinheiro et al., 2016 & 0.2 & 0.07 & 20 & 0.48 & 0.25 & 20 & $16.8 \%$ & $-0.28[-0.39,-0.17]$ & $*$ \\
\hline Ramazani et al., 2016 & 0.29 & 0.17 & 16 & 0.9 & 0.21 & 16 & $16.7 \%$ & $-0.61[-0.74,-0.48]$ & " \\
\hline \multirow{2}{*}{\multicolumn{7}{|c|}{$\begin{array}{l}\text { Total }(95 \% \mathrm{Cl}) \quad 128 \quad 128 \\
\text { Heterogeneity: } \text { Tau }^{2}=0.58 ; \mathrm{Chi}^{2}=820.95, \mathrm{df}=5(\mathrm{P}<0.00001) ; \mathrm{I}^{2}=99 \% \\
\text { Test for overall effect: } Z=1.18(\mathrm{P}=0.24)\end{array}$}} & $100.0 \%$ & $-0.37[-0.98,0.24]$ & \\
\hline & & & & & & & & & $\begin{array}{ccccc} & 1 & 1 & 1 & 1 \\
-4 & -2 & 0 & 2 & 4 \\
\text { Favours [reciprocating] } & \text { Favours [rotatory] }\end{array}$ \\
\hline
\end{tabular}

Figure 3. Meta-analysis considering working time (minutes) as outcome. 
Four studies [12-15] evaluated the cleaning ability of the root canals after implementing both kinematics. Two studies [12,14] performed the evaluation using a stereomicroscope based on the following scores: score 0: thorough ink removal, score 1: nearly thorough ink removal (remains of ink detected), score 2: partial ink removal (India ink remained in some areas), and score 3: no ink removal (a considerable amount of ink remained). Katge et al. [12] found that the reciprocating instrument (Wave-One) promoted better cleaning in the coronal and middle thirds of the root canals when compared to rotatory system (ProTaper). On the other hand, Ramazani et al. [14] did not find a difference between the reciprocating (Reciproc) and rotary (Mtwo) NiTi instruments.

Silva et al. [15] evaluated the cleaning ability of the root canals based on the presence of a smear layer following the scores: score 1: open dentinal tubules, without debris; score 2: open dentinal tubules, with debris covering less than $50 \%$ of the area; score 3: open dentinal tubules, with debris covering more than $50 \%$ of the area; and score 4: covered dentinal tubules and debris in $100 \%$ of the examined area. A greater cleaning ability for the reciprocating instrument (Wave-One) was only found in the coronal third when compared to ProTaper. Pinheiro et al. [13] evaluated the cleaning ability for Enterococcus Faecalis from root canals. There was no significant difference between the rotatory and the reciprocating NiTi instruments in the cleaning ability.

Ramazani et al. [14] also evaluated the file deformation when using Mtwo and Reciproc instruments as outcome. The files were examined under microscopic after each use and no instrument deformation or fracture was observed.

For the working time outcome, Prabhakar et al. [17] found that reciprocating instrument (WaveOne) resulted in a lower working time when compared to rotatory system (One-Shape).

\section{Discussion}

This is the first systematic review that compared the root canal preparation of primary teeth with reciprocating and rotary kinematics systems considering different outcomes such as cleaning ability, debris extrusion, file deformation or working time. The scientific literature has demonstrated that the use of NiTi instruments requires a shorter working time than hand files [6,22]. This factor is important in pediatric dentistry because it enables faster procedures while maintaining safety and quality, reducing fatigue of the patient and the professional [23]. The root canal preparation time is dependent on the technique and the operator's experience, as well as the number and type of instruments used. Three reciprocating kinematics (Wave One, Reciproc, and hand NiTi K-files under reciprocating motion) and four rotary systems (ProTaper, Twist File Adaptive, One Shape and Mtwo) were tested in the included studies. Normally, only one NiTi reciprocating instrument is used to prepare the root canal, while multiple rotary instruments must be used sequentially according to the manufacturer's instructions and trademark. The results of most included studies favored the reciprocating kinematics, and are generally recommended fewer instruments for the canal preparation when compared to rotary systems [13]. Pooled data showed no difference between the kinematics (rotary or reciprocating) considering working time. This may be explained due to few number of studies included.

During preparation, irrigating solutions and debris may be extruded by the apical foramen, leading to periapical inflammation, postoperative pain and delay of periapical healing [24]. Thus, the reduction or elimination of apical extrusion of infected debris can leads to more successful treatment rates. Although all preparation methods and instruments are associated with debris extrusion, the amount of debris extrusion may vary with techniques and the design of the file systems [25]. Reciprocating NiTi instruments were developed 
as a sort of mechanized balanced force technique for improving control of apically extruded debris to minimize the cyclic fatigue of the file, and prevent torsional fracture [8]. Despite that, the meta-analysis showed no difference in the debris extrusion between mechanical kinematics systems.

The heterogeneity found in the meta-analyses was moderate to high. Considering the limited number of studies and the methodological variability among them, heterogeneity is unavoidable. Four [12-15] included studies that evaluated the cleaning capacity of both kinematics. Two studies [12,14] used ink injection and clearing techniques for this purpose, one study reported the presence of a smear layer on the root canals [15], and another study [13] performed a microbiological evaluation before and after instrumentation. Thus, it was not possible to perform the meta-analysis.

One study [12] found that the reciprocating instrument (Wave-One) promoted better cleaning of the coronal and middle canal thirds when compared to continuous rotary system (ProTaper). Other study [14] did not find a significant difference between the groups (Reciproc and Mtwo). It is important to highlight that different NiTi instruments were tested in the selected studies and many aspects can interfere on the findings, such as the NiTi alloy, heat treatment, and cross-sectional design. According to the manufacturer's instructions, Wave-One must be brushed toward the canal walls, which can result in greater enlargement in the coronal third and consequently higher cleaning efficacy.

Although the primary molars uniformly exhibited buccopalatal widened canals [26], it might be inferred that the canal cross-section toward the coronal region might favor the action of both rotary and reciprocating instruments. The increasing diameter of dentinal tubules and the subsequent dentin softness toward the coronal third [27], when faced with mechanical instrumentation, may also be another contributing factor. Conversely, the presence of apical ramification may explain the insignificant difference between groups in the apical third. Enterococcus faecalis are an important cause of endodontic treatment failure, mainly because of microbial resistance after treatment [4]. Pinheiro et al. [13] found that both rotary and reciprocating instruments are effective in intracanal bacterial reduction.

Some included studies also considered shaping ability as an outcome [14,16-18], but it was not included in this review. Although this outcome is important for endodontic treatment of permanent teeth, this relevance is secondary in primary teeth. The presence of the permanent successor closes to the roots of primary teeth and physiologic root resorption difficult an accurate interpretation of the anatomy primary root canals [19].

Although a comprehensive literature search was undertaken through several databases, grey literature sources were not searched. Grey literature can reduce publication bias and facilitate a more balanced view of the evidence [28]. It has been shown that inclusion of grey literature may have an impact in situations where there are few relevant studies, or where there are questionable vested interests in the published literature [29].

Even though the risk of bias was low in most studies (50.0\% of all items across studies), the lack of information about sample size calculation is an important issue that impacts on the findings, and should be carefully considered in future in vitro studies. Furthermore, in vitro results cannot be directly extrapolated to clinical situations or to the instrument kinematic, which differs from those tested. Therefore, clinical trials focused on the efficacy of reciprocating and rotary NiTi instruments for cleaning and shaping of root canals during biomechanical preparation in primary teeth would be most essential to establish their clinical relevance.

\section{Conclusion}

There is no scientific evidence showing the superiority of reciprocating or rotatory NiTi instruments used for root canal preparation in primary teeth, considering debris extrusion and working time. 


\section{Authors' Contributions}

\begin{tabular}{|c|c|c|}
\hline LILB & (iD) https://orcid.org/0000-0002-6482-1399 & Methodology and Writing - Review and Editing. \\
\hline $\mathrm{CPC}$ & (i) https://orcid.org/o000-0001-9402-1811 & Methodology, Writing - Review and Editing and Project Administration. \\
\hline MMS & (iD) https://orcid.org/0000-0003-0934-876X & Methodology and Writing - Review and Editing. \\
\hline DP & (i) https://orcid.org/0000-0003-1717-9097 & Writing - Original Draft and Project Administration. \\
\hline $\mathrm{PAB}$ & (iD) https://orcid.org/0000-0002-4652-9095 & Writing - Original Draft. \\
\hline RAR & (iD) https://orcid.org/0000-0001-6568-7403 & Data Curation and Writing - Original Draft. \\
\hline LC & (iD) https://orcid.org/o000-0001-9515-6048 & Conceptualization, Writing - Original Draft and Project Administration. \\
\hline TLL & (iD https://orcid.org/0000-0003-3568-5217 & Conceptualization, Methodology, Formal Analysis and Writing - Original Draft. \\
\hline
\end{tabular}

\section{Financial Support}

None.

\section{Conflict of Interest}

The authors declare no conflicts of interest.

\section{Data Availability}

The data used to support the findings of this study can be made available upon request to the corresponding author.

\section{References}

[1] American Academy of Pediatric Dentistry (AAPD). Pulp therapy for primary and immature permanent teeth: An overview. Pediatr Dent 2017; 39(6):325-33

[2] Farsi NMA, Alamoudi N. Relationship between premature loss of primary teeth and the development of temporomandibular disorders in children. Int J Paediatr Dent 2001; 10(1):57-62. https://doi.org/10.1046/j.1365-263x.2000.00164.x

[3] Azar MR, Safi L, Nikaein A. Comparison of the cleaning capacity of Mtwo and Pro Taper rotary systems and manual instruments in primary teeth. Dent Res J 2012; 99(2):146-51. https://doi.org/10.4103/1735-3327.95227

[4] Silva LAB, Leonardo MR, Nelson-Filho P, Tanomaru JMG. Comparison of rotary and manual instrumentation techniques on cleaning capacity and instrumentation time in deciduous molars. J Dent Child 2004; 71(1):45-47.

[5] Hidalgo LRC, da Silva LAB, Leoni GB, Mazzi-Chaves JF, Carvalho EEDS, Consolaro A, et al. Mechanical preparation showed superior shaping ability than manual technique in primary molars - A micro-computed tomography study. Braz Dent J 2017; 28(4):453-60. https://doi.org/10.1590/0103-6440201601552

[6] Chugh VK, Patnana AK, Chugh A, Kumar P, Wadhwa P, Singh S. Clinical differences of hand and rotary instrumentations during biomechanical preparation in primary teeth - A systematic review and meta-analysis. Int $\mathrm{J}$ Paediatr Dent 202 1; 31(1):131-42. https://doi.org/10.1111/ipd.12720

[7] Bürklein S, Benten S, Schäfer E. Quantitative evaluation of apically extruded debris with different single-file systems: Reciproc, F360 and OneShape versus Mtwo. Int Endod J 2014; 47(5):405-9. https://doi.org/10.1111/iej.12161

[8] Yared G. Canal preparation using only one Ni-Ti rotary instrument: Preliminary observations. Int Endod J 2008; 41(4):339-44. https://doi.org/10.1111/j.1365-2591.2007.01351.x

[9] Liberati A, Altman DG, Tetzlaff J, Mulrow C, Gøtzsche PC, Ioannidis JPA, et al. The PRISMA Statement for Reporting Systematic Reviews and Meta-Analyses of Studies That Evaluate Health Care Interventions: Explanation and Elaboration. BMJ 2009; 6(7):e1000100. https://doi.org/10.1371/journal.pmed.1000100

[10] Krithikadatta J, Gopikrishna V, Datta M. CRIS guidelines (Checklist for Reporting In-vitro Studies): A concept note on the need for standardized guidelines for improving quality and transparency in reporting in-vitro studies in experimental dental research. J Conserv Dent 2014; 17(4):301-4. https://doi.org/10.4103/0972-0707.136338

[11] Higgins JP. Cochrane Handbook for Systematic Reviews of Interventions Version 5.1.o. The Cochrane Collaboration; 2011.

[12] Katge F, Patil D, Poojari M, Pimpale J, Shitoot A, Rusawat B. Comparison of instrumentation time and cleaning efficacy of manual instrumentation, rotary systems and reciprocating systems in primary teeth: An in vitro study. $\mathrm{J}$ Indian Soc Pedod Prev Dent 2014; 32(4):311-6. https://doi.org/10.4103/0970-4388.140957

[13] Pinheiro SL, Pessoa C, Da Silva JN, Gonçalves RO, Duarte DA, Da Silveira Bueno CE. Comparative analysis of protaper and waveone systems to reduce enterococcus faecalis from root canal system in primary molars - An in vitro study. J Clin Pediatr Dent 2016; 40(2):124-8. https://doi.org/10.17796/1053-4628-40.2.124

[14] Ramazani N, Mohammadi A, Amirabadi F, Ramazani M, Ehsani F. In vitro investigation of the cleaning efficacy, shaping ability, preparation time and file deformation of continuous rotary, reciprocating rotary and manual instrumentations in primary molars. J Dent Res Dent Clin Dent Prospects 2016; 10(1):49-56. https://doi.org/10.15171/joddd.2016.008 
[15] Silva BM, Scaini F, Tomazinho FSF, Gonzaga CC, Leão Gabardo MC, Baratto-Filho F. Root preparation of deciduous teeth: Efficacy of waveone and protaper systems with and without passive ultrasonic irrigation. Iran Endod J 2018; 13(3):362-6. https://doi.org/10.22037/iej.v13i3.17094

[16] Barasuol JC, Alcalde MP, Bortoluzzi EA, Duarte MAH, Cardoso M, Bolan M. Shaping ability of hand, rotary and reciprocating files in primary teeth: a micro-CT study in vitro. Eur Arch Paediatr Dent 2021; 22(2):195-201. https://doi.org/10.1007/s40368-020-00530-0

[17] Prabhakar AR, Yavagal C, Naik S V, Dixit K. Reciprocating vs rotary instrumentation in pediatric endodontics: cone beam computed tomographic analysis of deciduous root canals using two single-file systems. Int J Clin Pediatr Dent 2016; 9(1):45-9. https://doi.org/10.5005/jp-journals-10005-1332

[18] Jeevanandan G, Thomas E. Volumetric analysis of hand, reciprocating and rotary instrumentation techniques in primary molars using spiral computed tomography: An in vitro comparative study. Eur J Dent 2018; 12(01):21-6. https://doi.org/10.4103/ejd.ejd_247_17

[19] Alnassar I, Alsafadi AS, Kouchaji C. Assessment of the apically extruded debris between a rotary system, a reciprocating system and hand files during the root canal instrumentation of the deciduous molars. Dent Med Probl 2019; 56(1):53-7. https://doi.org/10.17219/dmp/99655

[20] Kucukyilmaz E, Savas S, Saygili G, Uysal B. Evaluation of apically extruded debris and irrigant produced by different nickel-titanium instrument systems in primary teeth. $J$ Contemp Dent Pract 2015; 16(11):864-8. https://doi.org/10.5005/jp-journals-10024-1772

[21] Gungor OE, Kustarci A. Evaluation of apically extruded debris using two Niti systems associated with two irrigation techniques in primary teeth. J Clin Pediatr Dent 2016; 4O(6):490-5. https://doi.org/10.17796/1053-4628-40.6.490

[22] Manchanda S, Sardana D, Yiu CKY. A systematic review and meta-analysis of randomized clinical trials comparing rotary canal instrumentation techniques with manual instrumentation techniques in primary teeth. Int Endod J 2020; 53(3):333-53. https://doi.org/10.1111/iej.13233

[23] Kummer TR, Calvo MC, Cordeiro MMR, de Sousa Vieira R, de Carvalho Rocha MJ. Ex vivo study of manual and rotary instrumentation techniques in human primary teeth. Oral Surgery, Oral Med Oral Pathol Oral Radiol Endodontology 2008; 105(4):84-92. https://doi.org/10.1016/j.tripleo.2007.12.008

[24] Seltzer S, Naidorf IJ. Flare-ups in Endodontics: I. Etiological factors manifestaciones agudas en endodoncia: I. Factores etiologicos. J Endod 1985; 1 1(1 1):472-8. https://doi.org/10.1097/00004770-200407000-00005

[25] Koçak S, Koçak MM, Sağlam BC, Türker SA, Sağsen B, Er Ö. Apical extrusion of debris using self-adjusting file, reciprocating single-file, and 2 rotary instrumentation systems. J Endod 2013; 39(10):1278-80. https://doi.org/10.1016/j.joen.2013.06.013

[26] Kielbassa AM, Uchtmann H, Wrbas KT, Bitter K. In vitro study assessing apical leakage of sealer-only backfills in root canals of primary teeth. J Dent 2007; 35(7):607-13. https://doi.org/10.1016/j.jdent.2007.04.006

[27] Versiani MA, Pécora JD, De Sousa-Neto MD. Flat-oval root canal preparation with self-adjusting file instrument: A micro-computed tomography study. J Endod 2011; 37(7):1002-7. https://doi.org/10.1016/j.joen.2011.03.017

[28] Paez A. Grey literature: An important resource in systematic reviews. Evid Based Med $2017 ; 2017$. https://doi.org/10.1111/jebm.12265

[29] Hartling L, Featherstone R, Nuspl M, Shave K, Dryden DM, Vandermeer B. Grey literature in systematic reviews: a cross-sectional study of the contribution of non-English reports, unpublished studies and dissertations to the results of meta-analyses in child-relevant reviews. BMC MedRes Methodol 2017; 17(1):64.

https://doi.org/10.1186/s12874-017-0347-Z 